\title{
Geomorphology and Quaternary History of the Australian Continental Dunefields
}

\begin{abstract}
R.J. WASSON
This summary paper forms part of a Japanese-Australian research project on human impact in the Australian semi-arid and arid zone. The dunefields are introduced in their various geologic and geomorphic settings and the sources and types of dune sands are then examined. The chronology of dune building is detailed from the earliest evidence of aeolian activity. This is followed by a reconstruction of the palaeoenvironment of the last dune building phases, an assessment of the impact of Aboriginal burning, and a concluding sketch of the impact of European settlement.
\end{abstract}

\section{The dunefields in their geologic and geomorphic settings}

Continental dunes of varying areal density occur on about $40 \%$ of the surface of Australia (Figure 1), making dunefields the most common landform assemblage, followed by uplands, alluvial plains, the coastal zone, lakes and volcanic landforms. Examples of the main dune types are shown in Figure 2. Linear dunes of different types are dominant in the dunefields, with linear narrow crested dunes outnumbering both broad crested linear dunes and very short narrow crested linear dunes. Network dunes, parabolic and crescentic dunes are relatively infrequent, although parabolics are common on coasts. There are no extensive areas of transverse dunes or star dunes in Australia, and barchans have not been reported. It must be noted that about $20 \%$ of the dunefield consists of dunes that cannot be adequately classified and these are referred to as "confused dunes." A thorough discussion of dune classification is provided by McKeE (1979).

Most of the linear dunes join in $y$-junctions which close in the direction of the modern sand-shifting wind resultants (WAsson, 1984a), and are thought to reflect both modern and past wind resultants. From the $y$ junctions, and orientation of parabolic and lunette dunes, the direction of movement of dunes can be determined (Figure 1). The dune orientation map depicts a continental- scale anti-clockwise whorl in which sand has been transported towards the east in the southern part of the dunefield, towards the north in the eastern part, and towards the west in the northern part of the whorl. The most recent mapping of the dunefield has augmented JenNings' (1968) map and now it is clear that the whorl is closed on its western side in the Gibson Desert of Western Australia. Despite the apparent potential for transport of sand over long distances around the whorl, grain size and petrographic data show that sand has not moved very far from its sources (WASSON, 1983a).

The Mallee, Strzelecki, Simpson and Great Sandy dunefields (Figure 1) lie largely in topographic basins which are also structural basins that took their present gross form in the Mid to Late Tertiary (Wasson, 1982). The other dunefields lie in topographically more complex areas. The Tanami dunefield lies on surfaces of low relief scattered between low ranges, dissected lateritic tablelands and plains, and dunes lie adjacent to floodlands and sandplains. The northern Gibson dunefield is simply an extension of the Great Sandy dunefield but further south the dunes lie between low tablelands and ridges; a landform pattern that extends into the Great Victoria dunefield. The western Gibson dunefield lies on the Yilgarn Plateau, and here the dunes lie along valleys set between lateritic breakaways, granitic plains and ridges of metamorphic rock (Jennings and Mabbutt, 1977).

\footnotetext{
* Division of Water and Land Resources, CSIRO, GPO Box 1666, Canberra, Australia, 2601.
} 


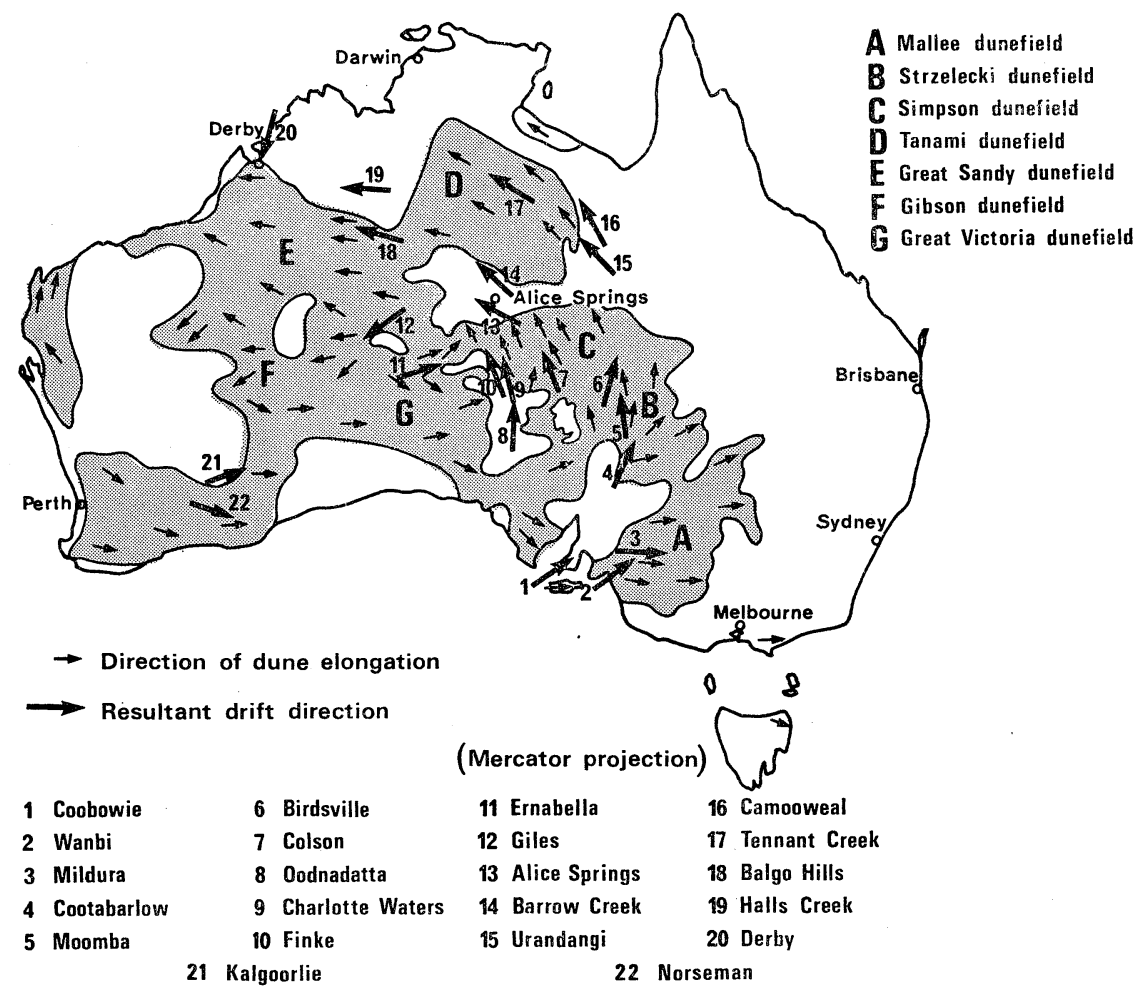

Figure 1. The major continental dunefields of Australia with directions of dune elongation and annual resultants of sand shifting winds.

The shaded part shows the area of dunefields.

The recently mapped (Figure 1) dunefield of southern Western Australia consists of dunes lying both in and downwind of shallow valleys cut in lateritic plains and stripped granitic plains. In the far southwest of the Yilgarn Plateau, the dunes border sources in shallow valleys on a gently sloping plateau of granite and gneiss.

The sources of sediment moulded into dunes are diverse in the Australian dunefields. They include stream and lake sediments that are still accumulating, relict lacustrine sediment, alluvium, and regressive marine sands. More specifically, the Simpson dunes were derived from actively accumulating alluvium along rivers in the south, from groundwater-controlled deflation of relict alluvium and lacustrine beds in the south-centre, and from relict alluvium in the north (WAsson, 1983a, b). In The Mallee the clayey linear dunes of the Woorinen Formation (CHURCHWARD, 1963; Bowler and MAGEe, 1978) were derived from fine-grained relict alluvium and Plio-
Pleistocene lake sediments (Blanchetown Clay) (LAWrence, 1980), while the sub-parabolic quartzose dunes of the Lowan Sand are derived largely from the Mio-Pliocene littoral to nearshore regressive Parilla Sand (LAWRENCE and Abele, 1976; Lawrence, 1980).

By contrast, in the Canning Basin, which underlies much of the Great Sandy dunefield, and in the Officer Basin, which underlies much of the Great Victoria dunefield, there is little evidence of the Cainozoic downwarping that has allowed relatively thick sequences of sediment to accumulate in the basins underlying The Mallee and Simpson dunefields. In the Officer Basin, sandstones of the Lampe Beds mark the beginning of a terrestrial fluviatile regime replacing the Cretaceous marine environment. The post-Lampe Bed expression of alluviation lies in palaeorivers that extend across both the Officer and Canning Basins (VAN DE GraAF et al., 1977). The age of the Lampe Beds suggests that the palaeorivers were initiated in the Eocene. The 


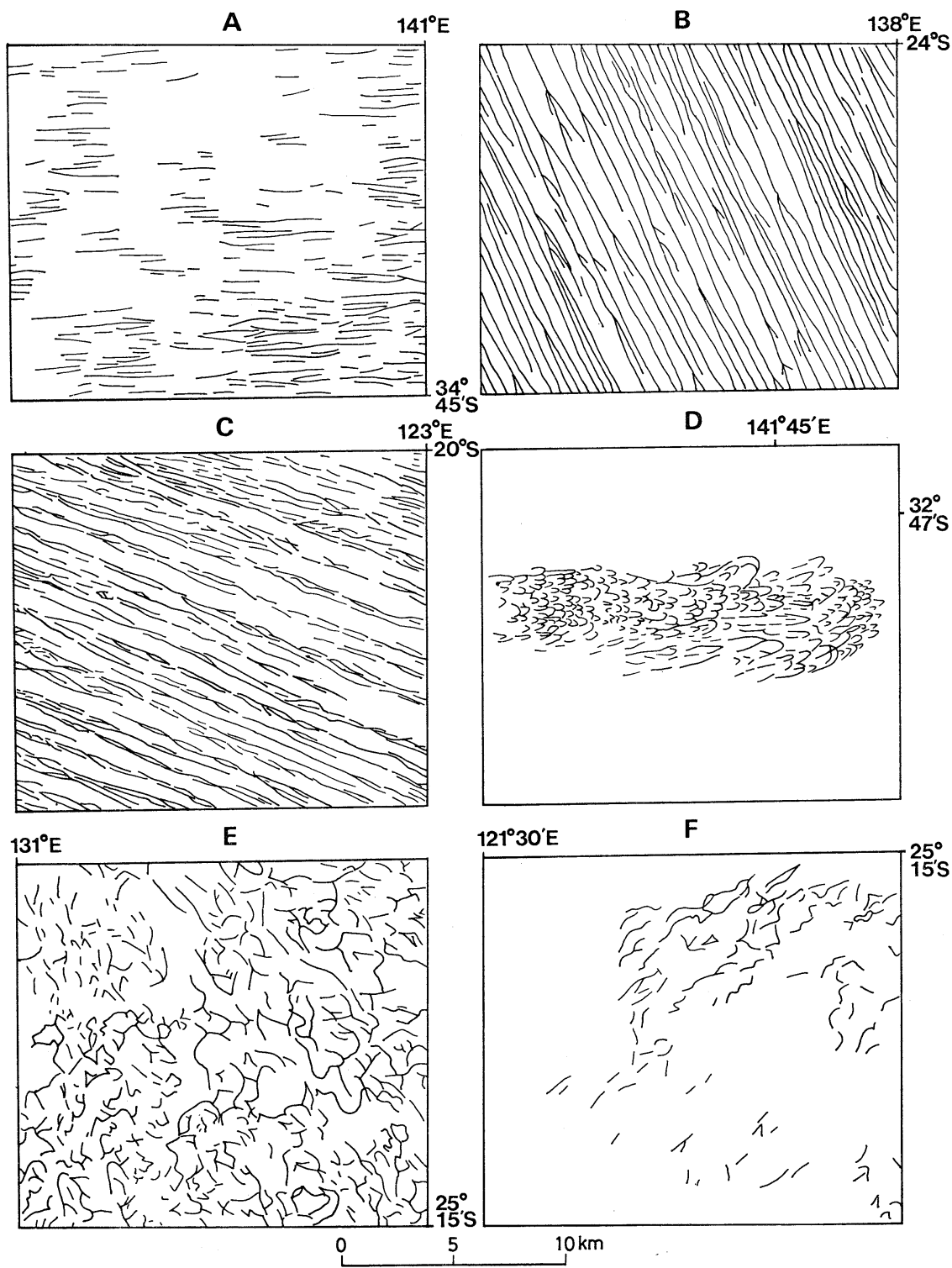

Figure 2. Main dune types found in the Australian continental dunefields. A : very short narrow crested linear dunes $B:$ long narrow crested linear dunes $\mathrm{C}:$ broad crested linear dunes $\mathrm{D}:$ parabolic and crescentic dunes $\mathrm{E}:$ network dunes $\mathrm{F}$ : confused dunes.

Late Cainozoic stratigraphy of the Officer and Canning Basins has not received serious attention, so that the events after the palaeodrainage became relict (probably in the Miocene) cannot be described. However, it is clear that: Quaternary sediments up to $20 \mathrm{~m}$ thick (excluding the height of dunes) occur in these basins (Geol. Surv. W.A., 1974); drainage lines younger than the "palaeodrainage" can be seen on aerial photographs; and the main sources of dune sands seem to have been alluvium and lake sediments. The palaeorivers have acted as sources, with linear dunes streaming downwind from areas such as Lake Auld in the Great Sandy dunefield.

In summary, there are profound differences between dunefields in Australia. At one end of the spectrum is the extensive well organized 
Simpson dunefield, the dunes in which are almost completely uninterrupted by hills and streams. At the other end of the spectrum is the western side of the Great Victoria dunefield where the landform pattern is a mosaic of lateritic plains, mesas, and palaeorivers, with the dunes forming small groups on relatively flat surfaces.

\section{Dune sediment types}

Most of the Australian continental dunes consist of fine to medium quartzose sands with small quantities of accessory minerals. These sands are derived from the various sources listed earlier and in most cases have been deflated from quartzose alluvium (WAsson, 1983a). In addition, Bowler (1973), Bowler and MageE (1978), Wasson (1983b), and SleEman and Stannard (1983a, b) have drawn attention to both transverse (lunette) dunes and linear dunes which are rich in clay. Microscopic examination of these sediments has shown that the clay occurs in sand-size aggregates which contain silt particles and clay exhibiting a flecked extinction pattern in polarized light. These aggregates (or pellets) have been observed in dunes in The Mallee, the Riverine Plain of southeastern Australia, the southwest of Western Australia, and in the Strzelecki and Simpson dunefields (Figure 1).

Pellets of similar size and type have also been found in clay-rich mantles on hills in the Riverine Plain (SleEman, 1982), on silcretecapped mesas on the edges of the Strzelecki dunefield (author's unpublished data) and on low hills north of Broken Hill (Chartres, 1982). These "clay blankets" are the "parna" of ButLer (1956) and represent a dust mantle deposited from aeolian suspension. Dust mantles can be expected downwind of the dunefields so we might eventually see their discovery in northern Australia.

The origin of the pellets may provide clues about the environment that prevailed during their formation and aeolian transport. BowLER (1973) argued for pelletization by salt crystallization as saline groundwater intersects lake floors in the case of lunette construction, and interdune swales in the case of linear dune formation. BowLER and WASSON (1984) suggest that the intersection of groundwater with the ground surface occurred after a long period of high water tables prior to 30,000 years B.P., the water table falling as evaporation and aridity increased. More recently, Bowler (pers. comm.) has suggested that the deflation of salts from lakes and boinkas (groundwater outcrops zones, Macumber, 1980) led to the widespread efflorescence of surfaces downwind. This idea means that the groundwater control of pelletization may have been less important than that produced by surface efflorescence downwind of salt sources.

The role of salts in pelletization is interpreted from the analogous features found in coastal sabkhas and lagoons in Africa and Texas, and processes presently occurring near Lake Tyrell (NW Victoria) and L. Eyre (N South Australia) (Bowler, 1973; Wasson, 1983b). However, pelletized alluvium does occur on the Riverine Plain under conditions which apparently deny to salt a significant role (SLeEman, 1982). The extraordinary structural stability of pellets in dunes of the Strzelecki dunefield, in the absence of carbonates or soluble salts, suggests either that baking in high daytime temperatures of algae/bacteria play a part in maintaining and perhaps initiating their form. Nanson (pers. comm.) has recently drawn attention to pellets transported by the modern Gooper Greek in central Australia, again in the absence of significant quantities of salts.

It is clear, however, that salt does play a major role in pelletization over large areas, both mechanically by crystallization and by providing an electrolyte for flocculation. WASSON (1983a, b) has shown that gypsum in the basal parts of dunes in the central Simpson Desert formed when saline groundwater rose into the shallow salinas that lie between the dunes. Gypsum in the alluvium that lies in interdunal swales of the Strzelecki dunefield also indicates groundwater fluctuations, comparable with the clearly recognizable evidence of groundwater outcrops in the boinkas of northwestern Victoria (Macumber, 1980). Recent observations by the author in the Murray Mallee (SE South Australia) showed that some linear dunes are built of interbedded quartzose sand, carbonate pellets and "millet-seed" gypsum, the last of which formed by authigenesis from a 
sulphate-rich brine in the interstices of mixed sediments lying below samphire flats in boinkas, and was subsequently deflated and blown into the dunes nearby.

In summary, there are two main types of sediment in the Australian continental dunes:

1. Quartzose sands that may contain a small number of clay particles derived from deflation of mud curls, but principally derived by climatically-controlled deflation of sandy alluvium.

2. Mixed clayey and quartzose sands containing varying contents of clay aggregates or pellets which can be partially calcareous, formed either by groundwater-controlled processes or by thermal and organic stabilization in the absence of significant quantities of salts. This facies has been split into two groups, the sandy clay and clay types (DARE-EDwARDS, 1982) based upon the relative proportions of clay pellets and quartz mineral grains. The pellets can obviously by suspended, thereby contributing to "parna," or clayrich dust, with modal particle diameters of 0.2 to $0.4 \mathrm{~mm}$. These diameters are much greater than would be expected in suspended aeolian sediments, probably because their low density allows long-distance transport.

\section{Chronology of dune building}

Most information comes from the Late Quaternary, for which there are radiocarbon dates both from the dunes and from stratigraphically related deposits such as lake-shore dunes and lake sediments. Bowler (1978), Bowler and WASSON (1984) and WASSON (1984a, b) have summarized these results. New previously unpublished data, and the results of Suzuki et al. (1982) and ToyA et al. (1985), have been combined with the summary of WAsson $(1984 \mathrm{a}, \mathrm{b})$ to give the most recent summary (Figure 3 ).

The histogram in Figure 3 has been compiled from three sources of data: radiocarbon dates of organic remains bedded within dunes; stratigraphic relations between dunes and other deposits, controlled by radiocarbon dates from either organic or inorganic carbon (soil car- (a)

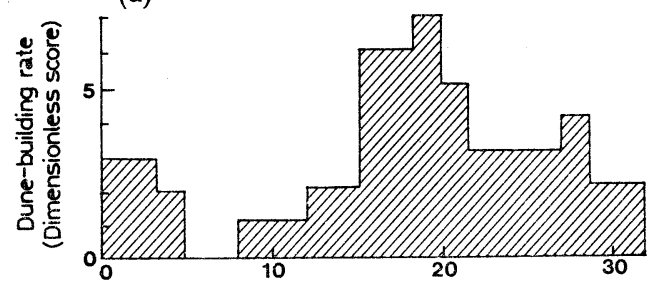

(b)
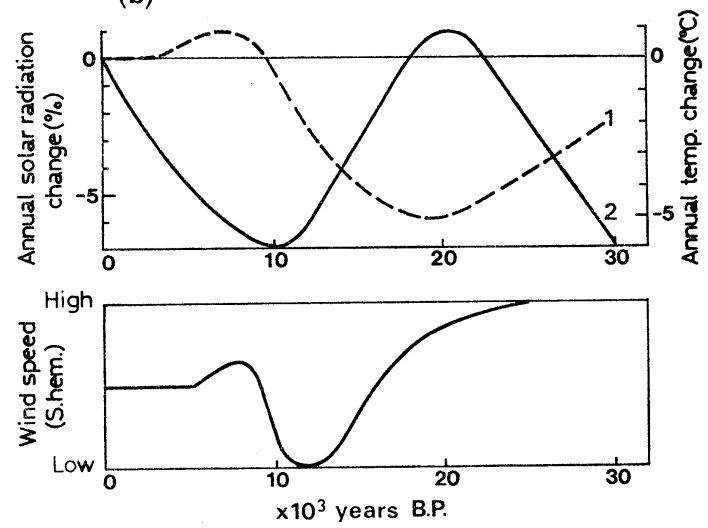

Figure 3. a. Histogram of age scores for dune building during the last 32,000 years for all dated sites in the Australian continental dunefields. b. For the same period is shown the change of mean annual temperature for the uplands of southeastern Australia (1) and solar radiation reaching the top of the atmosphere (2) calculated from orbital perturbations (from Chappell and GRINDrod, 1983).

Mean hemispheric wind speed is calculated from Chappell and Grindrod (1983), Wasson (1984a).

bonates usually providing minimum ages); thermoluminescence (TL) dates from the dune sands themselves. For each 1,000 year time interval from 0 to 32,000 years B.P., a score of 1 was given to one or more radiocarbon or TL dates from within a dune, and a score of 1 to each occurrence of a stratigraphically-determined age. This procedure weights the lastmentioned form of evidence because of the low probability of finding good radiocarbon dateable material in dunes. This system will obviously have to change once more TL dates become available.

The scores were added and are displayed in Figure 3. It is clear that most dune building 
occurred between 25,000 and 14,000 years B.P., with a peak between 20,000 and 16,000 years B.P. But dune building began about 30,000 years B.P., remembering that we are not here solely dependent upon radiocarbon dating which tends to become inoperative at $>30,000$ years B.P. Some dune building, or at least exposure of now buried sand to sunlight thereby "re-zeroing" the TL signal, occurred up to about 8,000 years B.P. This period of dune building coincides broadly with the main phase of the Würm/Wisconsin Glaciation, which is viewed as peaking at about 18,000 years B.P.

Renewed dune activity occurred in the Late Holocene, extending to about 1,000 years B.P. in the semi-arid zone and to the present-day in parts of the arid zone. The addition of sand to dunes in this period was a significant event but, in most places, does not equal the volume of sand deposited during the period coinciding with the Last Glacial Maximum. In addition, there is evidence to show that a lot of Holocene deposition resulted from reworking of older dune units.

TL dating of sediments (Wintle and Huntley, 1982) has now provided a means of extending the chrono-stratigraphy of dune building. REAdHEAD (1984; in prep.) has solved a number of problems in TL dating of sediments and we can have confidence in the calculated dates and their errors. TL dates derived by READHEAD and GARDNER et al. (in prep.) from The Mallee and Strzelecki dunefields respectively have been plotted in Figure 3. The errors are not shown but are about $10 \%$. In interpreting this diagram it must be noted that approximately the upper one metre of a litho-stratigraphic unit is often reworked either by wind or animals long after dune building has ceased. This is clear in the modern environment where, under largely undisturbed vegetation, fire and drought can lead to small-scale episodic remobilization by wind. The result is that TL dates from these upper levels are probably younger than the main phase of dune building, possibly explaining some of the quite young ages at the Pleistocene/Holocene boundary in Figure 3.

TL dates have also been obtained for dune sands older than those depicted in Figure 3. In
The Mallee and Strzelecki dunefields, reliable dates up to 200,000 years for the three or four youngest litho-stratigraphic units suggest that the entire sequence of five units at Nyah West (Churchward, 1963) in The Mallee may be less than 400,000 years old. Unfortunately the errors of TL dating, and the problem of reworking mentioned above, make direct correlation difficult between ages of dune construction and aeolian dust peaks in deep sea sediments.

With currently available techniques, no simple correlation can be detected between glacial peaks represented by $\delta^{18} \mathrm{O}$ maxima in deep sea cores and dune building events. The TL dates do suggest, however, that this correlation actually does not exist. The peak of the last glacial was a time of major dune construction but, since the last interglacial, it was not only period of such construction.

An additional but coarser view of the age of The Mallee dunes has been derived from magnetic reversal stratigraphy. BowLER (1982) showed that all five of the dune units at Nyah West were normally magnetized, that is, they lie in the Brunhes normal epoch and so are $-700,000$ years old. The TL and reversal dating are consistent, pointing to quite late development of aeolian landscapes in Australia by comparison with Tertiary development in the Namib and Sahara.

\section{Palaeoenvironmental reconstruction}

Most is known about the phase of dune building that coincided with the Last Glacial, dated between about 30,000 and 14,000 years B.P. Bowler et al. (1976) summarized the then available evidence for Late Quaternary climates in Australia, followed by WEBSTER and Streten's (1978) climatological model, and Chappell and Grindrod (1983) and WILFORD (1984) have given the most recent accounts. Bowler and WASson (1984) have synthesized evidence for glacial age environments in inland Australia, and WAsson (1984a) has concentrated on the palaeoclimates of the dunefields. The following is a summary of present views.

The dunefields preserve a record of changes in climatic zones ranging from summer mon- 
soonal regions in the north to the mid-latitude belt of anticyclones with winter rainfall in the south. The absence of orographic belts reduces the effect of local climate while the small area of glacial ice had little effect on climatic modifications. Thus the modern and past climatic pattern involves latitudinal migration of the Inter-Tropical Convergence Zone (ITCZ) and the Sub-Tropical Anticyclone Belt (STAB), both of which are relatively predictable and may be reconstructed for the past with some confidence.

Analysis of fluvial, aeolian and lacustrine sediments and landforms of the Australian interior shows the presence of two major events: a long period during which lakes in southern Australia were greatly expanded, followed by drying and accentuated aridity. The lacustral phase began about 50,000 years B.P, with oscillations beginning about 30,000 years B.P. and continuing with decreasing amplitude to about 20,000 years B.P. From about 30,000 years B.P. the fluctuations of lake level were accompanied by dune building, with extensive aeolian activity between 20,000 and 14,000 years B.P.

Within both the arid and semi-arid zones, high water tables associated with the early lacustral phase exerted a profound influence on the processes, compositions and forms of the subsequent dunes developed during the more arid phase. Thus saline pelletal clays originating from lake floors produced lunette dunes and deflation from salinized swales resulting in pelletal clay deposists in longitudinal dunes.

Global annual average temperatures were depressed during the dune building phase and so we can infer that the temperature-dependent part of potential evaporation was also lower. But glacial-age evaporite beds in saline lakes of inland Australia imply high evaporation rates. Ash and Wasson (1983) and Wasson (1984a) showed that, over much of the dunefield, modern vegetation cover is insufficient to stop major sand movement. The limit appears to be wind, that is, the modern environment is far less windy than the glacial environment. A minimum increase in windiness (expressed as percentage of days experiencing winds above the sand-moving threshold) by $20-30 \%$ would mobilize most of the dunes of Australia, thereby enhancing evaporation. In addition, calculations of orbitally controlled variations of solar energy reaching the earth (after Milankovitch) show that January radiation values at the Last Glacial Maximum (LGM) were at least as high as those of today and may have been $1 \%$ higher. The important role of modern summer radiation for evaporation shows that the LGM was a strongly evaporative time.

The reconstruction of environments of the LGM suggests that higher wind speeds and amplified advective heat transfer in glacial age summers resulted in evaporation rates higher than those of today. These were associated with colder glacial age winters, the accentuated seasonality reducing the growth period of vegetation in the inland and favouring higher runoff.

There has been considerable debate about whether or not the STAB moved northwards during the last glacial period as the meridional temperature gradient steepened. Both Brookfield (1970) and Webster and Streten (1978) argued against a simple patitudinal shift of the STAB, while SPRIGG (1982) argued strongly for it. A summary of palaeotemperature and palaeohydrologic data for the Southern Hemisphere by Harrison et al. (1984) has allowed application of a modified version of the Smagorinsky criterion for the mean latitude of the STAB. The criterion is dependent upon both the mean meridional gradient and the mean vertical lapse rate of equivalent potential temperature of the atmosphere. These authors concluded that during the last glacial, the equatorial trough and the STAB were compressed equatorward in both hemispheres.

Calculation of vector resultants for winds above the threshold of sand movement shows that there is significant divergence between longitudinal dune orientation and modern resultants in the southern Mallee dunefield and near Lake Frome in the southern Strzelecki dunefield (Wasson, 1984a). These anomalies can be explained by assuming that the STAB was northerly by about $5^{\circ}$ of latitude so that the westerlies were also much further north during the glacial. Such a move of the STAB would not be detectable in the northern 
Simpson Desert where BRookfield (1970) did her work. The other anomaly is at Derby on the northern edge of the Great Sandy Desert. Jennings (1975) has shown that at Derby the resultant for the dry season months parallels the dunes while the annual resultant, which includes the season (monsoon) northerly winds, is at right-angles to the dune trend. The weakening of the global monsoon circulation during the last glacial maximum (WAsson et al., 1983) presumably resulted in substantial withdrawal of the northern Australian monsoon. So during the last glacial the resultant was probably dominated by the Southeast Trades, a dune-parallel trend now reflected in the modern dry season winds.

The timing of Late Quatenary dune building events is broadly similar to that for other midlatitude dunefields of the world (cf. SARNTHEIN, 1978) but seems to be quite different from the Thar Desert of India where dune building has been controlled directly by the vigour and wetness of the southwest monsoon (WAsson et al., 1983). Stratigraphic evidence from the semi-arid part of the Thar shows that dune building began before 25,000 years B.P. and terminated between 6,000 and 1,000 years B.P., much later than in Australia. The explanation offered to explain this pattern is that the differential heating of the Indian Subcontinent and the Arabian Sea, which partially drives the monsoon, was reduced during the glacial period. So wind speeds were low but rainfall was also low. Wind velocity began to increase as global warming occurred during deglaciation, and velocities probably peaked at about 6,000 years B.P. when lakes in Rajasthan record a Holocene lacustral phase.

Dunes were slowly forming before global warming but became more mobile as wind speeds increased. Gradually, the increasing precipitation, and therefore increasing vegetation cover, overcame the strong winds in the Mid to Late Holocene, bringing dune building to an end. As the vigour of the monsoon waned in the Late Holocene in India, we see a resurgence of dune building activity in Australia. Chappell and Grindrod (1983) have shown from pollen diagrams that climate deteriorated slightly during the Late Holocene in Australia but insufficiently to explain dune reaction. WASSON (1984a) has suggested that the perturbing effects of extreme events (droughts, fires) were sufficient to allow incremental dune accumulation, especially during a period when the recovery times of vegetation had increased because of decreased rainfall.

\section{The impact of Aborigines}

It has been suggested by some prehistorians that the Aborigines of Australia could have had a dramatic impact on the stability of the landscapes of the inland through their use of fire. These people were not settled agriculturalists, although in certain areas they were quasi-sedentary particularly where food resources were rich. Fire was used traditionally by nomadic groups to stimulate fresh vegetation, remove unwanted vegetation, hunt animals, signal, reduce the chance of catastrophic fire by reducing fuel, and make walking easier.

Radiocarbon-dated archaeological sites at the Willandra Lakes in The Mallee dunefield shows that Aboriginal occupation pre-dates 35,000 years B.P. According to BowdLeR's (1977) hypothesis these people first colonized the north coast of Australia then migrated along the coasts and inland rivers, reaching the arid interior quite late. The earliest date for occupation on the edge of the arid zone is about 14,000 years B.P. from the Flinders Ranges (R. LAMPERT, pers. comm., 1984) and from the driest part of the continent 13,000 years B.P. (WAsson, 1983a). So there seems to be some support for BowDLER's argument but from very limited data.

How can we assess the impact of Aboriginal burning on the desert dunefields? The counting of carbonized particles in lake sediments, along with the analysis of pollen and archaeological sites, provides some hope of unravelling the respective impact of climate and people. Unfortunately, studies of this kind have not been carried out in the dunefields so our assessment can only be indirect. That is, can we see any evidence for severe diachronism between dune building and evidence for climate change taken from phenomena other than dunes? If we could, then we might be able to invoke Aboriginal burning as a possible cause. From 
presently available data the major phase of Late Quaternary dune building seems to coincide with a period when, from an array of evidence, we might expect dune building to have occurred. From this it can be concluded that the first-order control on dune building in Australia has been climate.

During the Holocene the number of archaeological sites increased sharply, especially during the Late Holocene when backed blades were manufactured ( $R$. LAMPERT, pers. comm.). In the Strzelecki dunefield, Holocene sites dominate and we might suppose that the population of Aborigines increased both in dry and wetter areas. This population increase may also have been associated with intensification of land use. Can we attribute the Late Holocene dune building phase to Aboriginal burning?

Again the coincidence of a climatic change, in this case only a minor shift, with dune building cannot be ignored. But there is local evidence that Aboriginal occupation of sites, and perhaps burning around about, could have degraded vegetation and allowed sand drift. At Oolgawa Waterhole on the western edge of the Simpson Desert, a number of radiocarbon dates from hearths show that major dune movement has occurred within the last 3,000 years. This Late Holocene unit is non-calcareous red-brown quartzose sand which can also be found on most dunes of the western Simpson. However, the thickness of the sand at Oolgawa is greater than elsewhere, suggesting an anthropogenic effect because of the intensity of occupation evident in this area. But even here we must be careful because the considerably greater thickness of sand at Oolgawa may be related not to Aboriginal occupation but to the periodic erosion of the downwing end of the dune by a creek, allowing the dune to cascade onto the floodplain and so build up a thickness of sand greater than that found on dune crests.

There is no proof that Aborigines had a major impact on the dunefields but there is evidence that the major control of dune building was climate.

\section{European impact}

European colonization started in 1788 in Sydney and spread gradually over much of the rest of the continent. The Aborigines were shot, killed by epidemics and dispossessed of their lands. Gradually the traditional Aboriginal way of life vanished, replaced by transplanted European land uses.

Sheep and cattle were raised on the extensive inland plains, and crops grown in the better watered areas. Forests were levelled in a search for grazing land as the pressure of the European population increased. The dunefields were colonized late, with wheat farmers moving into area such as The Mallee in the mid to late nineteenth century. Pastoralists followed the inland explorers like Charles Sturt and Ernest Giles, taking flocks of sheep into saltbush rangelands during the nineteenth century.

The early expectations were often unrealistically high so that sheep and cattle numbers in some areas at the beginning of this century were higher than anything that has been achieved since. Although drought and financial hardship have reduced both stock and settlers, the damage done to soils and vegetation during this early race to stock the continent is still apparent in degraded land.

The dunefields have escaped much of the ravaging that occurred in wetter areas, but The Mallee is the major exception. Here, the clearing of the multi-stemmed eucalypts (or mallees) exposed sandy soils to the wind. Large scale dust storms and sand drifts resulted and it has only been since the 1950's that techniques have been developed to stabilize these highly erodible areas.

Free-range grazing of the fringes of the other dunefields, combined with changes of fire regime resulting from the disappearance of the Aborigines, undoubtedly altered the vegetation. In some areas (e.g. SW Qld and W NSW) dunes were remobilized by overgrazing, followed by the invasion of inedible woody weeds. This invasion may also be a result of a changed fire regime.

The introduction of the rabbit has probably brought the greatest damage to areas like the Simpson/Strzelecki dunefield where entire 
dunes are honeycombed by burrows, the vegetation degraded allowing sand to move. The discovery of oil and gas in the Cooper Basin, underlying the Strzelecki dunefield, has brought extensive land use to a region which has been hitherto almost untouched. Road construction, seismic shot line bulldozing, pipeline laying, and settlement construction all have an effect but it is areally rather small.

European settlement has obviously degraded much of inland Australia but this process was aided by severe climatic conditions between 1915 and 1945 (cf. Ohmori et al., 1983). This is the time of the huge dust storms that carried red-brown particles across Sydney and Melbourne to New Zealand. Roads, edges of towns and railways were all threatened by drifting sands in The Mallee. From 1945 to 1983 dust storms and sand drift were dramatically lessened, partially by soil conservation practices and better agricultural management, but also by increased rainfall (Piтtock, 1975; Suzuki et al., 1982). A recent re-analysis of rainfall data throughout Australia (H. A. Nix, pers. comm.) has shown an increase of up to $16 \%$ in the Murray Mallee, $25 \%$ in the Broken Hill area, and as high as $40 \%$ in the Simpson Desert.

From unpublished analyses of regional climatology, and the works of PIтTоck et al. (1978) and Hessell (1984), it seems that between 1915 and 1945 the westerlies and southeast trades were stronger than between 1945 and 1983. The 1915-1945 period was more like the last glacial and the period 1945-1983 was more like an interglacial.

It follows that much of the damage which occurred to vegetation and soils during the early decades of this century was not solely the fault of European settlers. They were helped by unfavourable weather. But, equally, the continuing degradation must be largely the result of land-use practices because the weather has now ameliorated.

In the Murray Mallee the reworking of the last glacial aeolian sand since European settlement has been far more extensive than the reworking which occurred during the Holocene. It seems that, in some areas at least, our farming practices are far more devastating than a climatic change.

\section{Acknowledgement}

Dr R.W. Galloway usefully commented on the manuscript.

(Received February 7, 1986)

(Accepted March 1, 1986)

\section{References}

Ash, J. E. and WAsson, R.J. (1983): Vegetation and sand mobility in the Australian desert dunefield. Zeitschrift für Geomorphologie, N.F., Suppl., 45, 7-25.

BowDLER, S. (1977): The coastal colonization of Australia. In Allen, J., Golson, J., and Jones, R.: Sunda and Sahul, Academic Press, Sydney, 205-246.

Bowler, J. M. (1973): Clay dunes: their occurrence, formation and environmental significance. EarthScience Reviews, 9, 315-338.

Bowler, J. M. (1978): Glacial age aeolian events at high and low latitudes: a Southern Hemisphere perspective. In VAN ZINDEREN BaKkeR, E. M.: Antarctic Glacial History and World Palaeoenvironments, Balkema, 149-172.

Bowlen, J. M. (1982): Aridity in the Late Tertiary and Quaternary of Australia. In BARKER, W.R. and Greenslade, P.J.M.: Evolution of the Flova and Fauna of Arid Australia, Peacock Publications, 35-46.

Bowler, J. M., Hope, G. S., Jennings, J. N., Singh, G. and WALKER, D. (1976): Late Quaternary climates of Australia and New Guinea, Quaternary Research, 6, 359-394.

Bowler, J. M. and MAGEE, J. W. (1978): Geomorphology of the Mallee region in semi-arid northern Victoria and western New South Wales, Proceedings of the Royal Society of Victoria, 90, 5-26.

Bowler, J. M. and WAsson, R. J. (1984): Glacial Age environments of inland Australia. In Voger, J.C.: Late Cainozoic Palaeoclimates of the Southern Hemisphere, Balkema, 183-208.

Brookfield, M. (1970): Dune trends and wind regime in Central Australia, Zeitschrift für Geomorphologie, N.F., Suppl., 10, 121-153.

Butler, B. E. (1956): Parna-an aeolian clay, Australian Journal of Science, 18, 145-151.

Chappell, J. M. A. and Grindrod, A. (1983): CLIMANZ: A symposium of results and discussions concerned with Late Quaternary climatic history of Australia, New Zealand and surrounding seas, Department of Biogeography and Geomorphology, Australian National University, 2 Vols.

Chartres, C. J. (1982): Quaternary dust mantle soils in the Barrier Range, NSW. In WAsson, 
R.J.: Quaternary Dust Mantles of China, New Zealand and Australia, Department of Biogeography and Geomorphology, Australian National University, 153-160.

Churchward, H. M. (1963): Soil studies at Swan Hill, Victoria, Australia. II. Dune moulding and parna formation, Australian Journal of Soil Research 1, 103.

DARE-EDWARDs, A. J. (1982): Clay pellets of clay dunes: types, mineralogy, origin and effect of pedogenesis. In WASson, R. J.: Quaternary Dust Mantles of China, New Zealand and Australia, Department of Biogeography and Geomorphology, Australian National University, 179-190.

Gardner, G., Mortlock, A., Price, D., Readhead, M.L. and WASSON, R.J. (in prep.): Thermoluminescence and radiocarbon dating of dune building events in the Strzelecki Desert.

Geological Survey of Western Australia (1974): Geology of Western Australia, Western Australian Geological Survey, Memorandum 2, 541p.

Harrison, S. P., Metcalfe, S. E., Рittock, A. B., Roberts, C.N., SAlinger, M.J. and StreetPerrott, F.A. (1984): A climatic model of the Last Glacial/Interglacial transition based on palaeotemperature and palaeohydrological evidence. In Vogen, J.C.: Late Cainozoic Palaeoclimates of the Southern Hemisphere, Balkema, 21-34.

Hessell, J. W. D. (1984): Rainfall, zonal index and glacial variations on New Zealand's west coast since 1900. In Conference on Australian Rainfall Variability (Arkaroola), Australian Academy of Science and Bureau of Meteorology, Extended Abstracts, Part 1, 27-30.

Jennings, J. N. (1968): A revised map of the desert dunes of Australia, Austratian Geographer, 10, 408-409.

Jennings, J. N. (1975): Desert dunes and estuarine fill in the Fitzroy estuary (North-Western Australia), Catena, 2, 215-262.

Jennings, J. N. and MABbutt, J. A. (1977): Physiographic Outlines and Regions. In Jeans, D.N.: Australia, A Geography, Sydney University Press, 38-52.

LAwrence, C. R. (1980): Aeolian landforms of the Lowan Sand and Woorinen Formation in northwestern Victoria. In StorRIER, R.R. and STANNARd, M.E.: Aeolian Landscapes in the Semi-Arid Zone of South Eastern Australia, Australian Society of Soil Science, 57-64.

Lawrence, C. R. and Abele, C. (1976): Tertiary: Murray Basin. In Doyle, J.G. and Ferguson, J.A.: Geology of Victoria, Geological Society of Australia, Special Publication, 5, 191-198.

MACUMBER, P.G. (1980): The influence of ground- water discharge on the Mallee landscape. In Storrier, R. R. and Stannard, M. E.: Aeolian Landscapes in the Semi-Arid Zone of South Eastern Australia, Australian Society of Soil Science, 67-84.

MCKEE, E.D. (ed.) (1979): A study of global sand seas, U.S. Geological Survey, Professional Paper 1052.

Ohmori, H., Iwasaki, K. and TAKeuchi, K. (1983): Relationship between the recent dune activities and the rainfall fluctuations in the southern part of Australia, Geographical Review of Japan, 56, 131-150.

Piтtock, A. B. (1975): Climatic change and the patterns of variation in Australian rainfall, Search, 6, 498-504.

Pittock, A. B., Frakes, L. A., Jenssen, D., Peterson, J. A. and Z Illman, J. W. (eds.) (1978): Climatic change and variability: $A$ southern perspective, Cambridge Univ. Press, Melbourne.

ReAdHEAD, M. L. (1984): Thermoluminescence dating of some Australian sediments, Unpublished Ph.D. Thesis, Australian National University.

READHEAD, M. L. (in prep.): Thermoluminescence dating of sediments from southeastern Australia, Earth and Planetary Science Letters.

Sarnthein, M. (1978): Sand deserts during glacial maximum and climatic optimum, Natuve, 272, 43-46.

SleEman, J.R. (1982): Micromorphology of soils and deposits in the Riverine Plain and environs of southern NSW. In WASson, R. J.: Quaternary Dust Mantles of China, New Zealand and Australia, Department of Biogeography and Geomorphology, Australian National University, 173-178.

Sleeman, J. R. and Stannard, M. E. (1983a): $A$ buried bleached horizon in a Willbriggie (Parna) Ridge, Coleambally, NSW, CSIRO Division of Soils, Divisional Report 64.

Slemman, J. R. and Stannard, M. E. (1983b): $A$ parna lens in a soil vidge, Coleambally, NSW, CSIRO Division of Soils, Divisional Report 65.

SPRIGG, R. C. (1982): Alternating wind cycles of the Quaternary era and their influences on aeolian sedimentation in and around the dune deserts of southeastern Australia. In WAsson, R.J.: Quaternary Dust Mantles of China, New Zealand and Australia, Department of Biogeography and Geomorphology, Australian National University, 211240.

Suzuki, H., Uesugi, Y., Endo, K., Ohmori, H., TAKEUCHI, K. and IWASAKI, K. (1982): Studies on the Holocene and recent climatic fluctuations in Australia and New Zealand, University of Tokyo, Tokyo, $166 \mathrm{p}$.

Toya, H., TAKeuchI, K. and OHMORI, H. (eds.) 
(1985): Studies of environmental changes due to human activities in the semi-arid regions of Australia, Tokyo Metropolitan University, Tokyo, 317p.

VAN DE GRAAF, W. J. E. and JACKsON, M. J. (compilers) (1977): Geomorphology of the Officer Basin, Western Australia, Bureau of Mineral Resources, Geology and Geophysics, 1: 1,000,000 map.

WASsON, R.J. (1982): Landform development in Australia. In BARKER, W.R. and Greenslade, P.J.M.: Evolution of the Flova and Fauna of Arid Australia, Peacock Publications, 23-34.

WASson, R.J. (1983a): The Cainozoic history of the Strzelecki and Simpson dunefields (Australia), and the origin of the desert dunes, Zeitschrift für Geomorphologie, N.F., Suppl., 45, 85-115.

Wasson, R.J. (1983b): Dune sediment types, sand colour, sediment provenance, and hydrology in the Strzelecki-Simpson dunefield, Australia. In Brookfield, M.E. and Ahlbrandt, T.S.: Eolian Sediments and Processes, Elsevier, 165-195.

WAsson, R. J. (1984a): Late Quaternary palaeoenvironments in the desert dunefields of Australia.
In Vogel, J.C.: Late Cainozoic Palaeoclimates of the Southern Hemisphere, Balkema, 419-432.

WASSON, R.J. (1984b): Late Quaternary stratigraphy of Australian desert dunefields. In WILFord, G.E. (compiler): Quaternary studies in Australia: future directions, Bureau of Mineral Resources, Geology and Geophysics, Record 1984/14.

Wasson, R. J., Rajaguru, S. N., Misra, V. N., Agrawal, D. P., Dhir, R. P., Singhvi, A. K. and RAO, K.K. (1983): Geomorphology, late Quaternary stratigraphy and palaeoclimatology of the Thar dunefield, Zeitschrift für Geomorphologie, N.F., Suppl., 45, 117-152.

Webster, P. J. and Streten, N. A. (1978): Quaternary Ice Age climates of tropical Australasia: Interpretation and reconstructions, Quaternary Research, 3, 279-399.

WILFORD, G.E. (compiler) (1984): Quaternary studies in Australia: future divections, Bureau of Mineral Resources, Geology and Geophysics, Record 84!14.

Wintle, A. G. and Huntley, D. J. (1982): Thermoluminescence dating of sediments, Quaternary Science Reviews, 1, 31-53.

\section{オーストラリアの大陸砂丘地帯の地形と第四紀環境変遷}

$$
\text { ロバート J. ワッソン* }
$$

本稿はオーストラリア乾燥・半乾燥地域に和ける人間 活動化なう環境変化関する日濠共同研究の一環とし て, オーストラリア砂丘地帯の地学的背景や特徴ならび そ, 原住民抏よびョーロッパ人と砂丘活動々の関係につ いて概説したものである.

大陸の約 $40 \%$ は砂丘で覆われるが，バルハンを除く各 種の砂丘が分布する (Figure 2). これらの砂丘はシンプ ソン砂漠のように広域にわたって, 単純な線状砂丘が広 がる場合から，グレートビクトリア砂漠西部のように基 艦地形の複雑さを反映して，モザイク状に分布する場合 まで，その分布状態は変化㨽んでいる，また，砂丘砂 の給源も, 基盤岩石をはじめ, 河成堆積物など多種にわ たる.

砂丘堆積物の性格は 2 つに類型化される. 1 つは石英 砂を主としたもので，砂質河成堆積物を給源とする．他 の 1 つは粘土と石英粒の混合したるのである. 後者の堆 積物には粘土微粒子が含まれる.この粘土微粒子は比重 が小さいため空中を長距離運搬されてきたものである. 粘土微粒子の形成は地下水位の低下や日射飞よる塩類晶
出扣よび藻類やバクテリア等の生物起源と考光られ, 環 境変化の指標になる。

砂丘砂層の年代測定は ${ }^{14} \mathrm{C}$ 物よびサーモルミネッセン スによって行なった. オーストラリアの砂丘形成開始期 はスターレット砂漠で20万年 B.P. までさかのぼる. 、 リ一地域（大陸南部の現在の半乾燥地域）では 40 万年 B.P. より若いと推定され, 古地磁気の検討からも， 70 万年 B.P.よりは新らしいと考光られる.したがって， オーストラリアの砂丘形成はナミビ砂漠やサハラ砂漠に 比べて, きわめて新らしい時期始まったと言劣る. 最 終水期の砂丘形成は 3 万年 B.P. 前後から始をり， 2.5 万年 1.4 万年 B.P. の最終氷期の極相期に最も活発で あった (Figure 3). 完新世後期に砂丘形成は再び活発に なり, 半乾燥地域では 1,000 年 B.P. まで, 乾燥地域では 現在まで活動が続いている.

河成, 風成, 湖成堆積物和よび地形の検討からは, 内 陸地域の環境は 5 万年 B.P. 3万年 B.P. の湖沼が拡 大していた時期と 3 万年 B.P. 以降の湖水位が変動する 時期とに分けられる. 後者の時期には砂丘が活発に形成

*オーストラリア連邦科学技術研究機構, 水执よび土地資源局 
された．現在の風向・風速，日射，蒸発量呿よびミラン コヴィッチの曲線から推定される最終水期の日射量等を 考慮して, 上記の地学現象を検討すると, 次のような環 境が復元される，すなわち，砂丘形成が活発であった最 終水期の極相期には, 夏には風速が強く, 強い日射でも あったため，現在よりも蒸発が盛んで，乾燥していた。 冬は低温で, 植生の生育期間は短縮される傾向にあり, 雨水の流出は高弯っていた.

な特，承期の砂丘の伸長方向之現在の風向との検討か ら, 承期飞は亜熱帯高圧帯は現在より $5^{\circ}$ 程度北上してい たこと，大陸北部では，モンスーンが弱まっていたため 南東貿易風が卓越していたことが推定される(Figure 1). アボリジニーズの砂丘形成に対する影響は火（野火）
の使用によって引き起されると考穴られる. 乙かし，砂 丘形成の主たる原因は気候であることを示す証 拠が多 く，アボリジニーズの影響を示す証拠はほとんど知られ ていない。

ヨーロッパ人入植後, 土地の劣悪化が急速に進み1915 〜1945年の間に砂丘の活発な再活動もあった。この時期 には, 気候の乾燥化捄よび風速の増加があり, ヨーロッ パ人の入植に加光, 気候悪化が生じたため, 砂丘活動が 発生したと言学よう，一方，1945年以降，オーストラリ アの降水量は增加している. 乙かし, 砂丘活動は引き続 き継続している，そ故，少なくとも一部の地域では, 農耕行為が砂丘活動に大きな影響を与えているものと思 われる。

（文責・大森博雄） 